\title{
An Estimation of Technical Efficiency of Red Chili Pepper's Growers in Central Bangka
}

\author{
Rati Purwasih, Novyandra Ilham Bahtera*, and Yulia \\ Agribusiness Department, Bangka Belitung University, Bangka, Indonesia
}

\begin{abstract}
In Central Bangka, The red chili pepper's productivity is still considered at low level. It is corroborated from comparison between the productivity of red chili pepper which is computed as 35.6 quintal per hectare while the potential productivity of the genetics of red chili pepper is 200-220 quintal per hectare. It is presumed that the productivity of red chili pepper is technically inefficient. The aim of the study is to analyze factors that affect the production of red chili pepper and the technical inefficiency. The study also determines the level of technical efficiency of red chili pepper on smallholders who participate in the agriculture productivity improvement program in Central Bangka Regency. Survey was carried out to collect the data with purposive sampling method. The criteria of respondents were those red chili pepper smallholders who had involved with the agriculture productivity improvement program. The total sampled respondents were 43 smallholders. Stochastic frontier analysis with the Maximum Likelihood Estimate was used to analyze the data. The study discovered the factors that affect the production of red chili pepper were labor, potassium fertilizer, insecticide, and fungicide. Furthermore, the productivity of red chili pepper was considered as technically inefficient which was shown from the average score of technical efficient, 0.54 . Finally, the study revealed that side job became factor that could increase the technical inefficiency of red chili pepper farming activity while the frequency of attending the empowerment program and farmer field school were otherwise.
\end{abstract}

Keywords: Bangka Belitung; red chili pepper smallholder; technical efficient

Received 17 March 2020 | Revised 31 March 2020 | Accepted 15 April 2020

\section{Introduction}

One of the most vital economic sectors as the source of income and job opportunity for the society is agriculture sector [1]. It is demonstrated from its contribution to the gross domestic product (GDP). In 2018, GDP price index illustrates that the agriculture sector ranked second in contributing the economic growth in Indonesia which is $12.81 \%$ of the GDP [2]. The agriculture sector consists of some sub-sectors which are crops, horticulture, plantation, livestock, forestry and fisheries. Statistic [2] shows that horticulture contributes $1.47 \%$ of the $12.81 \%$ contribution of agriculture sector in GDP. One of the horticulture commodities is red chili pepper. Decree of the Minister of Agriculture number. 830/Kpts/RC.040/12/2016 decides the location of the national agriculture development. Bangka Belitung Islands Province has been chosen as the

\footnotetext{
*Corresponding author at: Agribusiness Department, Bangka Belitung University, Bangka, Indonesia

E-mail address: novyandra.ib@gmail.com
} 
location of the national agriculture development. The red chili pepper is prioritized in the program [3].

The agriculture productivity improvement program is launched to support the government policy on the national agriculture development on the red chili pepper in Central Bangka. The program is considered as new program as it has begun on September, 2017. The objective of the program is to stabilize inflation and stimulate the smallholder's welfare so that it can boost the development of a particular area [4]. The well-run program will affect ability in achieving the productivity target of red chili pepper. The Production, harvested area, productivity of red chili pepper in Central Bangka Regency can be seen in Table 1.

Table 1. The Production, Harvested Area, Productivity of Red Chili Pepper in Central Bangka Regency, January-August 2017

\begin{tabular}{clccc}
\hline No & \multicolumn{1}{c}{ District } & $\begin{array}{c}\text { Production } \\
\text { (quintal) }\end{array}$ & $\begin{array}{c}\text { Harvested Area } \\
\text { (ha) }\end{array}$ & $\begin{array}{c}\text { Productivity } \\
\text { (quintal/ha) }\end{array}$ \\
\hline 1 & Koba & 40 & 2.21 & 18.19 \\
2 & PangkalanBaru & 491 & 15.15 & 32.41 \\
3 & Sungaiselan & 190 & 8.03 & 23.66 \\
4 & Simpangkatis & 313 & 4.60 & 68.04 \\
5 & Namang & 120 & 2.00 & 60.00 \\
6 & Lubukbesar & 200 & 6.05 & 33.06 \\
\hline & Total & 1,354 & 38.04 & 35.60 \\
\hline
\end{tabular}

Source: Agriculture Department of Bangka Belitung Islands Province (2017)

In 2017, the red chili pepper productivity in Central Bangka Regency is 35.6 quintal per hectare (Table 1). It illustrates that its red chili pepper productivity is considered as low because the potential productivity of the genetics of red chili pepper should be 200-220 quintal per hectare. It can be presumed that the red chili pepper business is technically inefficient. It might be due to the inability of smallholders in optimizing the use of factors of production (input) in the chili production as well as the low level of knowledge in implementing good crop management practices.

The socio-economic characteristics of smallholders were observed as another reason to make the growers technically inefficient is. Anggraini [1] argues that efficient level of cassava business is affected by both the use of input and socio-economic profile of smallholders. The variables of socio-economic profile that affect the inefficiency are age, years of experience, household size, level of education, membership of farmer group, extension, credit access, and others. Those affect the managerial skill of smallholders in producing cassava so that it can influence the efficiency level of cassava production. Anggraini [5] further argues that the efficiency level is affected by farming technique, the use of factors of production and socio-economic profile of smallholders. Thus, the productivity improvement of red chili pepper through technical efficient is crucial to be conducted. It is crucial to study the issue on the endeavor to improve the productivity of red chili 
pepper through technical efficiency. Thus, the study aims to identify the technical efficiency and to determine the factors that affect the technical inefficiency of red chili pepper farming activity for those smallholders who participate in the agriculture productivity improvement program in Central Bangka.

The objective of business is to maximize profit [6] so the productive efficiency becomes crucial. The business actor avoids the technical and allocative inefficiency as it leads to the loss profit [7]. Some factors that lead to technical inefficiency are age, year of schooling, irrigation infrastructure [8] and land [9]. Production efficiency relates with the level of maximum profit. There are two reasons why the production process is inefficient which are: (i) technically inefficient due to the unsuccessful in achieving the maximum productivity and (ii) allocative inefficiency due to the suboptimum of the input use [7] [10] [11].

Some of main elements in the technology application are any input used in the farming activity, the quantity, the frequency, and the production method. Next, the managerial skills will be reflected from the production of the harvested crops as well as the level of education reflected by the experience of smallholders in farming activity [11]. The farming activity is considered as highly efficient is when smallholders can produce nearly the maximum potency of particular agriculture commodity. Furthermore, the level of education plays an important role in measuring the managerial skills. The higher level of education is held by smallholders, the higher chance in creating innovation. As it is believed that the experience on the farming activity is one of factors that support in improving the performance of smallholders in farming activity [12].

The study on technical efficiency has been done in India by Mohapatra [13] who argues that labor and NPK fertilizer positively influence the technical efficiency of rice farming activity while compost fertilizer and capital depreciation are the opposite. Furthermore, he states that years of experience in farming activity and educational attained affect the technical inefficiency of rice farming activity.

\section{Research Methods}

Four villages in Central Bangka were chosen as the location of research which were Belilik, Sungkap, Keretak and Trubus. Those villages were chosen as they were some of locations of agriculture productivity improvement program that were considered as having low level of red chili pepper productivity. Purposive sampling was used in collecting data to 43 respondents using survey method. Table 2 illustrated the distribution of respondents. 
Table 2. The Amount of Smallholders in Four Villages, Central Bangka

\begin{tabular}{ccccc}
\hline No & $\begin{array}{c}\text { Name of Farmer } \\
\text { Group }\end{array}$ & Village & $\begin{array}{c}\text { Amount of Member } \\
\text { (persons) }\end{array}$ & $\begin{array}{c}\text { Amount of } \\
\text { Smallholder (persons) }\end{array}$ \\
\hline 1 & Air Danau 2 & Belilik & 33 & 18 \\
2 & BerkahTani & Sungkap & 5 & 5 \\
3 & Sukamaju & Keretak & 22 & 12 \\
4 & Citra & Trubus & 8 & 8 \\
\hline & & & 43 \\
\hline
\end{tabular}

Stochastic Frontier Analysis was employed to address the research question. Cobb-Douglas production function with maximum likelihood estimated was applied in analyzing the red chili pepper production. Farrell [14] was the first person who wrote the article on the issue of measuring the productive efficiency. Afterwards, many scholars used the theory such as [15] and [16].

The following is the mathematical equation of the mentioned production function [9]:

$$
\begin{aligned}
\ln \mathrm{y}= & \beta_{0}+\beta_{1} \ln \mathrm{x}_{1}+\beta_{2} \ln \mathrm{x}_{2}+\beta_{3} \ln \mathrm{x}_{3}+\beta_{4} \ln \mathrm{x}_{4}+\beta_{5} \ln \mathrm{x}_{5}+\beta_{6} \ln \mathrm{x}_{6}+\beta_{7} \ln \mathrm{x}_{7}+ \\
& \beta_{8} \ln \mathrm{x}_{8}+\left(\mathrm{v}_{\mathrm{i}}-\mathrm{u}_{\mathrm{i}}\right)
\end{aligned}
$$

where: $\mathrm{y}=$ Production of red chili pepper $(\mathrm{Kg}) ; \mathrm{x}_{1}=$ Amount of seed $(\mathrm{Gram}) ; \mathrm{x}_{2}=$ Amount of labor (HKP); $\mathrm{x}_{3}=$ Amount Nitrogen fertilizer $(\mathrm{kg}) ; \mathrm{x}_{4}=$ Amount of Phosphorus fertilizer $(\mathrm{kg}), \mathrm{x}_{5}$ $=$ Amount of Potassium fertilizer $(\mathrm{kg}) ; \mathrm{x}_{6}=$ Amount of insecticide (liter); $\mathrm{x}_{7}=$ Amount of fungicide $(\mathrm{Kg}) ; \mathrm{x}_{8}=$ Amount of agricultural lime $(\mathrm{Kg}) ; \mathrm{V}_{\mathrm{i}}=$ error term shows the uncertainty of the assumed production $(0, \sigma v) 2 ; \mathrm{u}_{\mathrm{i}}=$ showing the assumed technical inefficient $(0, \sigma \mathrm{u})^{2}$ and $\mathrm{u}$ $>0$, ui independent towards vi.

The expected regression coefficient: $\beta_{1}, \beta_{2}, \beta_{3}, \beta_{4}, \beta_{5}, \beta_{6}, \beta_{7}, \beta_{8}>0$

The level of technical efficient could be calculated using the following formula[9]:

$$
\mathrm{TE}_{\mathrm{i}}=\frac{\mathrm{y}_{\mathrm{i}}}{\exp \left(\mathrm{x}_{\mathrm{i}} \beta\right)}=\frac{\exp \left(\mathrm{x}_{\mathrm{i}} \beta-\mathrm{u}_{\mathrm{i}}\right)}{\exp \left(\mathrm{x}_{\mathrm{i}} \beta\right)}=\exp \left(-\mathrm{u}_{\mathrm{i}}\right)
$$

The main factors of technical inefficient were analyzed using the equation as follows[9]:

$$
\mathrm{U}_{\mathrm{i}}=\delta_{0}+\delta_{1} \mathrm{z}_{1}+\delta_{2} \mathrm{z}_{2}+\delta_{3} \mathrm{z}_{3}+\delta_{4} \mathrm{z}_{4}+\delta_{5} \mathrm{z}_{5}
$$

where: $\mathrm{Ui}=$ Technical efficient score; $\mathrm{z}_{1}=$ Amount of family member (persons); $\mathrm{z}_{2}=$ Frequency of attending the agricultural extension (times); $\mathrm{z}_{3}=$ Frequency of attending the farmer group meeting (times); $\mathrm{z}_{4}=$ Side job $(0=$ no, $1=$ yes $) ; \mathrm{z}_{5}=$ Participating in training $(0=$ no, $1=$ yes $)$ 
The expected estimating parameter: $\delta_{1}, \delta_{2}, \delta_{3}, \delta_{5}<0, \delta_{4}>0$

\section{Results and Discussion}

\subsection{Production Function and Technical Efficiency Analysis on Red Chili Pepper Farming Activity in Central Bangka}

An agriculture commodity should have input to produce output. The production's inputs can affect the production level of a particular commodity. Thus, inputs were assumed to play a vital role in the production of red chili pepper in the agriculture productivity improvement program in Central Bangka. These inputs were seed, labor, phosphorus fertilizer, potassium fertilizer, insecticide and fungicide. Stochastic frontier production function analysis was computedto ensure whether all inputs affected the production level of red chili pepper. on the estimated results are illustrated in Table 3.

Table 3. Estimation Results of Stochastic Frontier Production Function on Red Chili Pepper Farming Activity in Central Bangka

\begin{tabular}{lccc}
\hline \multicolumn{1}{c}{ Variable } & Coefficient & Std.Error & t-ratio \\
\hline Seed & -0.51 & 0.18 & $-2.67^{*}$ \\
Labor & 0.09 & 0.07 & $1.23^{*}$ \\
Phosphorus fertilizer & -0.72 & 0.38 & $-1.89^{*}$ \\
Potassium fertilizer & 0.63 & 0.35 & $1.79^{*}$ \\
Insecticide & 0.57 & 0.15 & $3.80^{*}$ \\
Fungicide & 0.23 & 0.05 & $4.99^{*}$ \\
Sigma-squared & 2.64 & & \\
Gamma & 0.99 & & \\
Log likelihood function & -33.41 & & \\
LR test of the one-sided error & 37.46 & & \\
\hline
\end{tabular}

Note: *significant, confidence level at $\alpha 25 \%$

Table 3 illustrated that there were four out of six variables which affect significantly towards production of red chili pepper in Central Bangka. The variables were labor, potassium fertilizer, insecticide and fungicide affect positively significant towards production of red chili pepper while seed and phosphorus fertilizer were computed as significant but had inverse relationship with chili's yield. The study was supported by Saddozai et. al., [17] that inputs played a significant role in the production.

Table 3 figured that the potassium fertilizer affected the productivity of red chili pepper farming activity positively significant at the confidence level $\alpha=25 \%$, with the estimating parameter on 0.63 . It meant that the additional $1 \%$ of potassium fertilizer can increase $0.63 \%$ of the productivity of red chili pepper, estimating other production factors remained constant. The potassium fertilizer was the most responsive variables in increasing the red chili pepper productivity as the 
estimating parameter score of potassium fertilizer was bigger than others. It implied that government should prioritize potassium fertilizer in the agriculture productivity improvement program. The result of the study was in line with [18] and [19] that discovered the potassium fertilizer affected the red chili pepper positively significant.

Labor, insecticide, fungicide were also affected positively significant towards the red chili pepper productivity with the coefficient level at $0.09,0.57$ and 0.23 respectively. Those showed the additional $1 \%$ of the mentioned variables can increase the red chili pepper production in the agriculture productivity improvement program counting $0.09 \%$ (labor), $0.57 \%$ (insecticide), and $0.23 \%$ (fungicide), assuming other factors remained.

On the other hand, seed and phosphorus fertilizer affected significantly but inversely towards the red chili pepper productivity at the confidence level $\alpha=25 \%$. The estimating parameter score of both variables is -0.50 (seed) and -0.72 (phosphorus fertilizer). It indicated that the additional $1 \%$ of both variables can decrease the red chili pepper productivity in the agriculture productivity improvement program counting $0.50 \%$ (seed) and $0.72 \%$ (phosphorus fertilizer), assuming other factors were constant. Furthermore, $\operatorname{Gamma}(\gamma) 0.99$ with the confidence level at $1 \%$ on the error term from inefficiency factor (ui). It indicated that the estimating parameter of inefficiency were valid [20].

The production function of stochastic frontier was used to analyze the technical efficiency of red chili pepper farming activity. The maximum score of technical efficiency was 0.99 while the minimum was 0.04 . Furthermore, 0.54 was the average score of technical efficiency of red chili pepper farming activity. It indicated that the input level and available technology could increase $46 \%$ productivity of red chili pepper. Thus, the agriculture productivity improvement program was considered as technically inefficient as the score of technical efficiency was lower than 0.7 [20].

\subsection{Factors Affecting the Technical Inefficiency of Red Chili Pepper Farming Activity in Central Bangka}

Table 4 showed that there were three out of five explanatory variables that affected the technical inefficiency of red chili pepper farming activity with the confidence level at $\alpha=25 \%$, were farmer group meeting, side job earnings and farmer field school while agricultural extension and member of family were the opposite. The reason why member of family did not affected the technical inefficiency was because most of the members of family were still students so that they did not participate in the activity of red chili pepper's production. 
Table 4. Estimating Results on the Effect of Technical Inefficiency towards the Red Chili Pepper Farming Activity

\begin{tabular}{lccc}
\hline \multicolumn{1}{c}{ Variable } & Coefficient & Std.Error & t-Ratio \\
\hline Member of family & -0.19 & 0.31 & -0.61 \\
Frequency of agricultural extension & -0.16 & 0.49 & -0.32 \\
Frequency of farmer group meeting & -0.10 & 0.08 & $-1.28^{*}$ \\
Side job & 3.56 & 0.97 & $3.67^{*}$ \\
Farmer field school & -2.39 & 1.28 & $-1.87^{*}$ \\
\hline
\end{tabular}

Note: * significant

The frequency of farmer group meeting significantly affected towards the technical inefficiency of red chili pepper farming activity with the confidence level at $\alpha=25 \%$ and parameter score at 0.10. It meant that the more frequent attending the farmer group meeting, the more reducing of the technical inefficiency of red chili pepper was.

The meeting normally discussed about the red chili pepper farming activity, the use of fertilizer and the way how to exterminate pests and diseases of red chili pepper. As a result, smallholders earned enough information about red chili pepper farming activity. In turns, the technical inefficiency can be reduced. 13 times was the average times in attending the agriculture productivity improvement program. It took from the analysis of the frontier program at each farmer's technical efficiency score. It was then grouped based on the available range to determine the amount of farmer who had efficiency score at each range.

Side job is another variable that affected significantly towards the technical inefficiency of red chili pepper farming activity with the confidence level at $\alpha=25 \%$ and parameter score at 3.56. It meant that those smallholders who had side job would increase the technical inefficiency compared with those who had no side job. It could be explained that smallholders who had side job were considered as having inability in prioritizing the red chili pepper farming activity. Table 5 showed that there were 18 respondents who had side job but were inefficient while only seven smallholders who were both having no side job and inefficient.

Table 5. The Distribution of Smallholders by the Efficiency Level based on Side Job

\begin{tabular}{ccccc}
\hline \multirow{2}{*}{$\begin{array}{c}\text { Efficiency } \\
\text { Distribution }\end{array}$} & \multicolumn{2}{c}{ Side Job } & Persons & $\begin{array}{c}\text { Percentage } \\
\text { (\%) }\end{array}$ \\
\cline { 2 - 3 } & Yes & No & 18 & 41.86 \\
0.50 & 15 & 3 & 8 & 18.60 \\
$0.50-0.69$ & 4 & 4 & 10 & 23.26 \\
$\geq 0.90$ & 7 & 3 & 7 & 16.28 \\
Total & 4 & 3 & 43 & 100 \\
\hline
\end{tabular}

Next, the technical efficiency of red chili pepper farming activity were also influenced by farmer field school. -2.39 was the estimating parameter score. It indicated that the participation on the farmer field school could reduce the technical inefficiency. The farmer field school provided some 
lesson materials. They were the use of seed, fertilizing and plant protection. It showed that there were only 15 respondents who involved with the farmer field school. The study was supported by [17] which stated that the FFS farmers was considered having more significantly efficient that the non FFS farmer one. They were considered as having technical efficiency score while the rest was otherwise (Table 6).

Table 6. The Distribution of Smallholders by Level of Efficiency based on Farmer Field School

\begin{tabular}{|c|c|c|c|c|}
\hline \multirow{2}{*}{$\begin{array}{c}\text { Efficiency } \\
\text { Distribution }\end{array}$} & \multicolumn{2}{|c|}{$\begin{array}{l}\text { Farmer Field } \\
\text { School }\end{array}$} & \multirow{2}{*}{$\begin{array}{c}\text { Amount of Family Member } \\
\text { (persons) }\end{array}$} & \multirow{2}{*}{$\begin{array}{l}\text { Percentage } \\
\quad(\%)\end{array}$} \\
\hline & Yes & No & & \\
\hline$<0.50$ & 15 & 3 & 18 & 41.86 \\
\hline $0.50-0.69$ & 8 & 0 & 8 & 18.60 \\
\hline $0.70-0.89$ & 10 & 0 & 10 & 23.26 \\
\hline$\geq 0.90$ & 7 & 0 & 7 & 16.28 \\
\hline Total & 40 & 3 & 43 & 100 \\
\hline
\end{tabular}

\section{Conclusion and Suggestions}

The study concludes that, labor, potassium fertilizer, insecticide and fungicide are contributing significantly to the red chili pepper productivity in Central Bangka while seed and phosphorus fertilizer use must be rationalized to avoid its inverse association with chili productivity. The farming activity of red chili pepper considered as technically inefficient as the average score of technical efficient was 0.54 . While the technical inefficiency of red chili pepper farming activity was influenced by frequency of farmer group meeting, side job and farmer field school. On the other hand, agricultural extension and member of family had no significant role in affecting technical inefficiency.

It is suggested that the use of input production is adjusted with the good agricultural practices so that the use of input can be optimized. It also requires the adequate agricultural extension of red chili pepper farming activity to enrich the knowledge of smallholders.

\section{Acknowledgments}

We thank to the Ministry of Research, Technology, \& Higher Education for the financial support on the process of fieldwork activities under the scheme of Penelitian Dosen Pemula/Research Grants for Beginner Lecturer. We also would like to thank LPPM (Lembaga Penelitan dan Pengabdian Masyarakat/Institute for Research and Community Services) of Bangka Belitung University for the moral and administrative support so that the research can run well.

\section{REFERENCES}

[1] Nuni Anggraini, "Efisiensi pada Usahatani Ubikayu di Kabupaten Lampung Tengah Provinsi Lampung," Institut Pertanian Bogor, 2015. 
[2] Badan Pusat Statistik. Distribusi PDB Triwulanan Atas Dasar Harga Berlaku Menurut Lapangan Usaha (Persen), 2014-2018," Jakarta, 2019.

[3] Kepementan, "Lokasi Pengembangan Kawasan Pertanian Nasional," Jakarta, 2016.

[4] Widyastuti, "Respon Petani terhadap Program Peningkatan Produktivitas Cabai Merah (Capsicum annuum, L.) di Kabupaten Bangka Tengah,” Universitas Bangka Belitung, 2018.

[5] N. Anggraini, H. Harianto, and L. Anggraeni, "Efisiensi Teknis, Alokatif dan Ekonomi pada Usahatani Ubikayu di Kabupaten Lampung Tengah Provinsi Lampung," J. Agribisnis Indones., vol. 4, no. 1, p. 43, 2017.

[6] Z. A. Khan, "Profit maximisation as an objective of a firm - A robust perspective," Int. J. 'Research Financ. Mark., vol. 7, no. 6, pp. 217-219, 2017.

[7] F. Ellis, Peasant Economics (Petani Gurem: Rumah Tangga Usahatani dan Pembangunan Pertanian). Malang: Bayu Media dan UMM Press, 2003.

[8] A. Wadud, B. E. N. White, A. Wadud, and B. E. N. White, "Department of Economics , Delhi School of Economics, University of Delhi The Determinants of Technical Inefficiency of Farms in Bangladesh The Determinants of Technical Inefficiency of Farms in Bangladesh," vol. 37, no. 2, pp. 183-197, 2014.

[9] T. J. Coelli, D. S. P. Rao, C. J. O'Donnell, and G. Battese, An Introduction to Efficiency and Productivity Analysis. London (UK): Kluwer Academic Publishers., 1998.

[10] N. Sumaryanto, W. Maghraby, and M. Siregar, "Determinan Efisiensi Teknis Usahatani Padi di Lahan Sawah Irigasi," J. Agro Ekon., vol. 21, no. 1, p. 72, 2016.

[11] Saptana, "Konsep Efisiensi Usahatani Pangan dan Implikasinya bagi Peningkatan Produktivitas," Forum Penelit. Agro Ekon., vol. 30, no. 2, pp. 109-128, 2012.

[12] Gusmawati, A. Laapo, and D. Howara, "Analisis Kelayakan Usahatani Cengkeh di Desa Bou Kecamatan Sojol Kabupaten Donggala Provinsi Sulawesi Tengah," Agrotekbis, vol. 2, no. 3, pp. 325-331, 2014.

[13] R. Mohapatra, "Farm Level Technical Efficiency in Paddy Production: A Translog Frontier Production Function Approach," Int. J. Adv. Res., vol. 1, no. 3, pp. 300-307, 2013.

[14] M. J. Farrell, "The measurement of productive efficiency," J. R. Stat. Soc., vol. 120, no. 3, pp. 253-290, 1957.

[15] D. Aigner, C. A. K. Lovell, and P. Schmidt, "Formulation and estimation of stochastic frontier production function models," J. Econom., vol. 6, no. 1, pp. 21-37, 1977.

[16] W. Meeusen and J. van Den Broeck, "Efficiency Estimation from Cobb-Douglas Production Functions with Composed Error," Int. Econ. Rev. (Philadelphia)., vol. 18, no. 2, pp. 435444, 1977.

[17] K. N. Saddozai, A. Saboor, A. Khan, D. Jan, and G. Ali, “Analyzing the Impact of Farmer Field School on Technical Efficiency of Cotton Growers in Southern Districts of PunjabPakistan : Stochastic Production Frontier Approach,” vol. 29, no. 2, 2013.

[18] N. Saptana, A. Daryanto, H. K. Daryanto, and N. Kuntjoro, "Analisis Efisiensi Teknis Produksi Usahatani Cabai Merah Besar dan Perilaku Petani dalam Menghadapi Risiko," $J$. Agro Ekon., vol. 28, no. 2, p. 153, 2016.

[19] G. W. Pranata and L. Damayanti, "Faktor-Faktor Yang Mempengaruhi Produksi Usahatani Cabai Merah Kriting Di Desa Bolupountu Jaya, Kecamatan Sigi Biromaru, Kabupaten Sigi," J. Agrol., vol. 23, no. April, pp. 11-19, 2016.

[20] N. Kusnadi, N. Tinaprilla, S. Hery Susilowati, and A. Purwoto, "Analisis Efisiensi Usahatani Padidibeberapa Sentra Produksi Padi di Indonesia,” J. Agro Ekon., vol. 29, no. 1, pp. 25-48, 2011. 